\title{
An Overview of Earthquake Science in Malaysia
}

\author{
Felix Tongkul ${ }^{1 *}$ \\ ${ }^{1}$ Natural Disaster Research Centre, Faculty of Science and Natural Resources, University Malaysia Sabah
}

This paper highlights the level of earthquake hazard in Malaysia, the challenges in mitigating earthquake hazard and the way forward on how to strengthen earthquake science in Malaysia. Earthquake hazard is regarded as low throughout Malaysia, with the exception of Sabah where it is considered moderate. This elevated level of a hazard was reinforced during the 2015 Ranau Earthquake, which killed 18 people. Despite this and other recent sizeable earthquakes, the earthquake hazard in Malaysia is poorly understood, yet the population has increased, and growth in buildings and infrastructure has risen. While much progress has been made since the 2015 Ranau earthquake in terms of the development of (i) national seismic hazard map; (ii) national seismic building code; and (iii) planning guideline in a high-risk earthquake area, there are still many challenges faced in mitigating earthquake hazard in Malaysia. There is still a lack of seismic, geological, geodetic and engineering data; insufficient seismic and geodetic monitoring network system; lack of trained human resources; and lack of public awareness. To ensure that earthquake hazard is properly quantified and mitigated some steps have to be taken, which includes (i) comprehensive geological, geotechnical and engineering studies; (ii) coordinated seismic and geodetic monitoring; (iii) human resource capacity building; (iv) coordinated public education; (v) allocation of special research and development grant; and (vi) setting up of a National Earthquake Research Centre.

Keywords: earthquake hazard; geological mapping; earthquake monitoring; capacity building; public education

\section{INTRODUCTION}

Earthquake science deals with the scientific understanding of earthquake processes (origin and properties), their consequences and mitigation. Earthquake science encompasses the multidisciplinary field of geology, geodesy, rock mechanics and physics of complex system apart from seismology.

The main goal of earthquake research is to learn how to predict the behaviour of earthquake systems. The prediction has come to mean the accurate forecasting of time, place, and size of specific large earthquakes, ideally in a short time to allow nearby communities to prepare for a calamity. Unfortunately, accurate prediction of the earthquake is still not possible at this stage due to the complexity of earthquake systems. No clear signals before the occurrence of the large earthquake have been identified.

However, many aspects of earthquake behaviour can be anticipated with enough precision to be useful in mitigating risk. The potential of near-surface faults to cause future earthquakes can be assessed by combining geological field studies of the previous slippage with seismic and geodetic monitoring of current activity.

Seismologists learn how geological complexity controls the strong ground motion during earthquakes, and engineers are learning how to predict the effects of seismic waves on buildings, lifelines, and critical facilities such as large bridges, dams and nuclear plants. Together, geologists, seismologists and engineers have quantified long-term expectations for potentially destructive shaking in the form of seismic hazard maps.

*Corresponding author's e-mail: ftongkul@ums.edu.my 
Earthquake science in Malaysia is still in its infancy and exploratory stage. Geologists, seismologists and engineers are talking to each other only recently, when "forced" to produce a seismic hazard map of Malaysia. Thus opportunities for research in the field of earthquake science in Malaysia is thus wide open.

This paper provides a general summary of the level of earthquake hazard in Malaysia, the challenges faced in mitigating the earthquake hazard and proposes some strategic measures to strengthen earthquake science in Malaysia. It is hoped that some of these measures can be included in the disaster risk reduction (DRR) program on earthquake in Malaysia.

\section{EARTHQUAKE HAZARD IN MALAYSIA}

Malaysia is affected by both regional and local earthquakes. Significant earthquakes from West Sumatra have been felt several times in Peninsular Malaysia (Figure 1). The USGS earthquake data shows about 50 earthquakes with a magnitude more than 6.0 (Mw) lies within $1000 \mathrm{~km}$ from Kuala Lumpur since 1973. Although the effect is small, it is still of concern, especially to vulnerable high rise buildings. Similarly, earthquakes from the Sulu and Celebes seas are periodically felt as slight tremors in Sabah. The USGS earthquake database shows a total of 221 earthquakes with magnitude more than 6.o (Mw) within $1000 \mathrm{~km}$ from Kota Kinabalu since 1973. Rare earthquake from Kalimantan is felt as slight tremors in Sarawak.

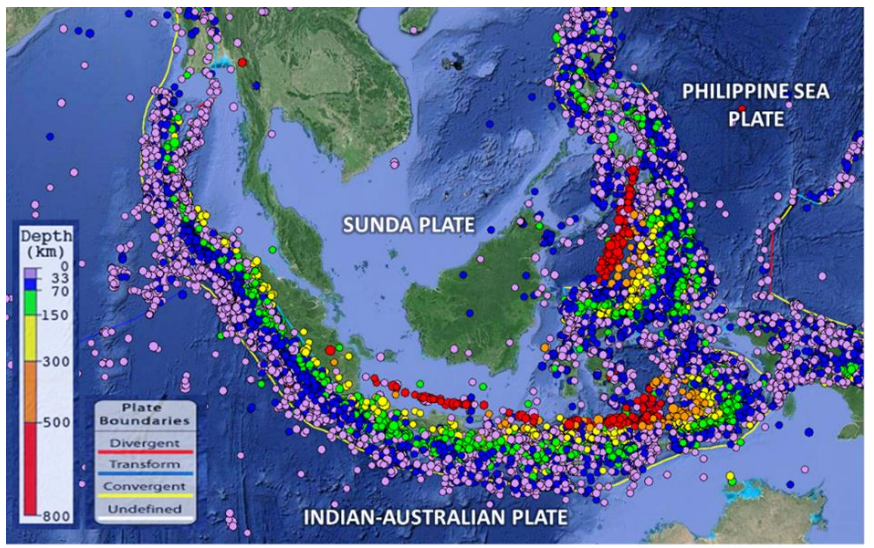

Figure 1. Distribution of regional earthquake (magnitude more than $5 \mathrm{Mw}$ ) surrounding Malaysia. The colour of the dots corresponds to the depth of the earthquake. Data from
USGS earthquake database.

The presence of earthquakes in Malaysia are closely associated with plate tectonic movements in this region (Figure 2). Peninsular Malaysia sitting on the Sunda Shelf lies passively behind the active Great Sumatran Fault (GSF) Zone and Sunda Trench Subduction Zone. Global Positioning System (GPS) measurements indicate rates of movements of between 2-5 cm/yr along the Great Sumatra Fault Zone (Natawidjaja \& Triyoso, 2007). To a certain extent, Sabah and Sarawak sitting on the semi-stable South China Sea Basin are influenced by the active mobile belts in Sulawesi and Philippines. GPS measurement in Sabah indicates intra-plate crustal deformation which may be related to the SundalandPhilippine convergence (Mustafar et al., 2014; Mustafar et al., 2017). The active Sulu Trench subduction zone continues into East Sabah (Tongkul, 1991). Similarly, the movement along the Palu-Koro Fault (PKF) in Sulawesi appears to affect Southeast Sabah (Rangin et al., 1990). GPS measurement of movement across the Palu-Koro Fault showed $3.4 \mathrm{~cm} / \mathrm{yr}$ leftlateral strike-slip movement (Walpersdorf et al., 1998). In the South China Sea, the NW Borneo Trough (NWST) which was probably once associated with subduction zone is not seismically active. Active thrust faults found along the trough may mostly be associated with sedimentary loading and slumping or crustal shortening (Sapin et. al., 2013; Hall, 2013; King et. al., 2010; Hesse et al., 2009).

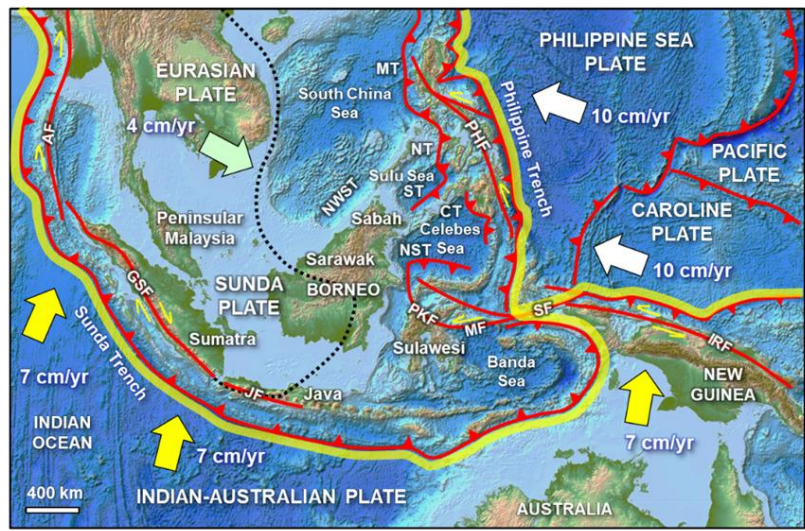

Figure 2. Major plate boundaries (thick yellow line) and movements in Southeast Asia. Malaysia lies away from the active plate boundaries along the Sunda Trench and Philippine Trench. The Indian-Australian Plate moving northwards (7 cm/yr). The Philippine-Caroline-Pacific Plate moving relatively faster towards the west $(10 \mathrm{~cm} / \mathrm{yr})$. MT: 
Manila Trench, NT: Negros Trench, ST: Sulu Trench, CT: Cotabato Trench, NST: North Sulawesi Trench, NWST: NW Sabah Trough, PHF: Philippine Fault, PKF: Palu-Koro Fault, MF: Matano Fault, SF: Sorong Fault, IRF: Irian Fault, AF: Andaman Fault, GSF: Great Sumatran Fault, JF: Java Fault

The source of regional earthquake for Peninsular Malaysia comes from the active Great Sumatra Fault Zones and Sunda Trench Subduction Zone (or Sunda megathrust) which extends across the Andaman Sea. The source of regional earthquakes for Sabah comes from the active subduction zones marked by the Philippine Trench, Manila Trench, Negros Trench, Sulu Trench, Cotabato Trench and North Sulawesi Trench.

\section{A. Earthquake in Peninsular Malaysia}

Earthquakes felt in Peninsular Malaysia since the early 1800 s are mostly related to earthquakes from Sumatra and Andaman Islands (Leyu et al., 1985). Since 1970, earthquake records from the Incorporated Research Institutions for Seismology Earthquake Database (IRIS) shows local earthquakes in Peninsular Malaysia. Since 2007, Malaysia Meteorology Department (MMD) recorded several small local earthquakes in Peninsular Malaysia (Figure 3). These earthquakes, mostly less than $4 \mathrm{Mw}$ in magnitude are located in Bukit Tinggi in Pahang, Kuala Pilah in Negeri Sembilan and Tasik Temenggor in Perak occurred after 2006. These local earthquakes are probably related to reactivation of ancient faults (Mustaffa et al., 2017; Ismail et al., 2015). Except for creating some minor tremors and shaking of highrise buildings, these earthquakes have not resulted in any significant damage.

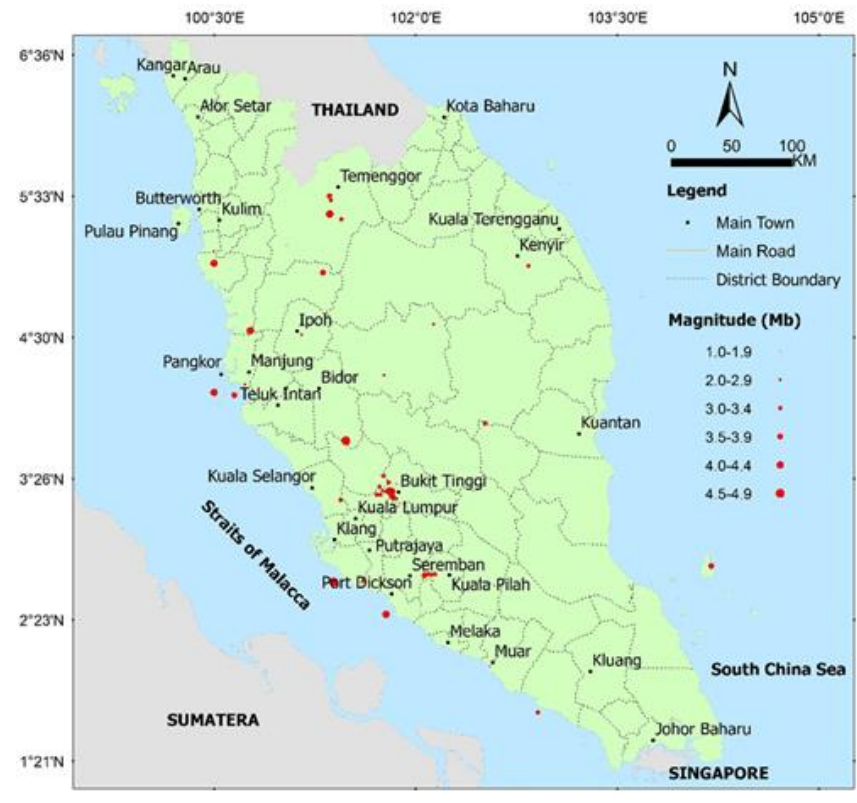

Figure 3. Earthquake distribution in Peninsular Malaysia based on MMD and IRIS Earthquake Databases (19702018). The earthquakes are concentrated in Bukit Tinggi,

Kuala Pilah, Manjung, Temenggor and Kenyir.

\section{B. Earthquake in Sarawak}

Earthquakes felt in Sarawak are mostly related to local earthquakes. Leyu et al. (1985) documented several historical minor earthquakes around Kuching, Samarahan, Bintulu, Bekenu and Niah areas. During the period from 1970 to May 2019, about 20 light to moderate (magnitude larger than 3.0 $\mathrm{Mw}$ ) earthquakes were recorded onshore Sarawak (Figure 4). Most of the earthquakes have magnitude less than 5.0 Mw except for two which were recorded at Batu Niah and Bukit Mersing. Most of the earthquakes were recorded after 2006. These earthquakes appears to be related to N-S trending active sinistral strike-slip faults in the Niah area and NW-SE trending dextral strike-slip faults near Bukit Mersing area. These earthquakes caused minor damage to buildings. 


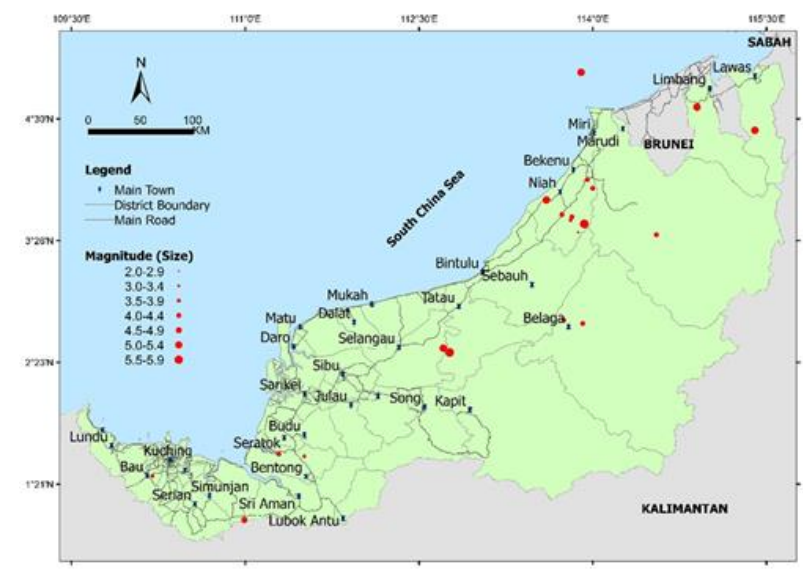

Figure 4. Distribution of earthquakes in Sarawak based on MMD and IRIS earthquake databases. The earthquakes are mostly located around Niah and Selangau.

\section{Earthquake in Sabah}

Earthquakes in Sabah are mostly generated locally with some located in the Sulu and Celebes Seas. Wilford (1969) and Lim (1985) record several historical earthquakes felt in Sabah that are not well documented in the USGS earthquake database. These historical earthquakes occurred mostly in Tawau, Lahad Datu, Sandakan, Kudat and Keningau.

Based on USGS earthquake database, during the period from 1900 to 2019, about 67 light to moderate (magnitude larger than 3.5 Mw) earthquakes were recorded onshore and offshore Sabah (Figure 5). Most of the earthquakes in Sabah have a magnitude less than 5.0 $\mathrm{Mw}$, apart from four earthquakes with magnitude 6.o Mw and above, such as the 2015 Ranau earthquake (6.0 Mw), 1976 Lahad Datu earthquake (6.2 Mw), 1951 Kudat earthquake (6.1 Mw) and 1923 Lahad Datu earthquake (6.3 Mw). The earthquakes are concentrated in Ranau and Lahad Datu areas.

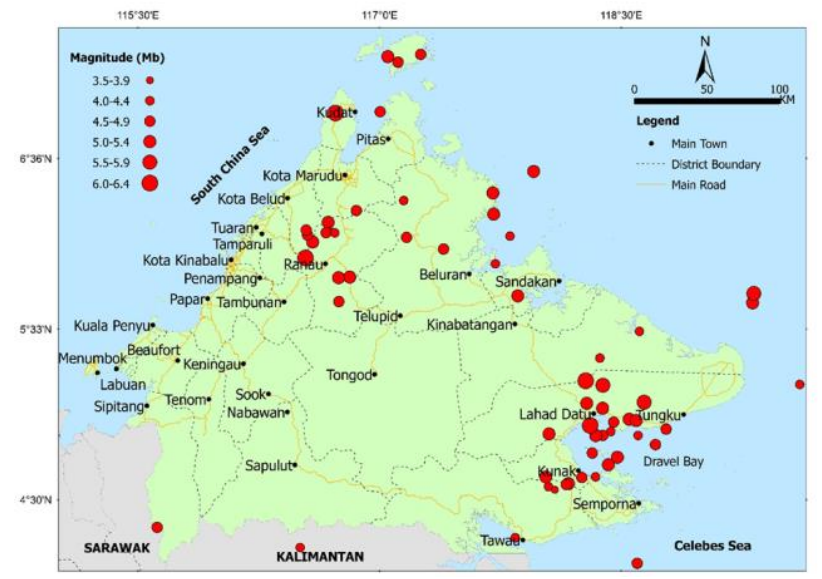

Figure 5. Earthquake distribution in Sabah (1900-2019) extracted from USGS earthquake database.
The relatively small number of earthquakes shown by the USGS earthquake database is due partly to the detection limit of older seismographs in Sabah. However, since the establishment of new seismographs in Sabah more micro earthquakes have been recorded in Sabah (Figure 6). For example, during 2015 alone, MMD recorded 155 small earthquakes (magnitude larger than 2.o Mw) in Sabah.

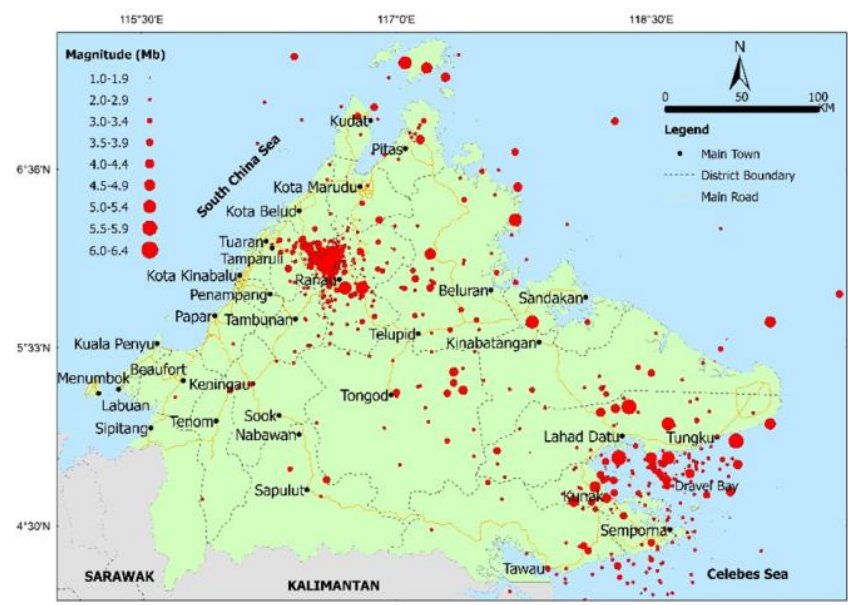

Figure 6. Earthquake distribution in Sabah (1966-2019) based on MMD (2019). There is a heavy concentration of very small earthquakes in Ranau and Darvel Bay areas.

The earthquakes in Sabah are associated with active faults, comprising of thrust faults, strike-slip faults and normal faults (Tongkul, 1989 \& 2017; Wang et al., 2017; Tongkul \& Omang, 2010; Tjia, 1978 \& 2007).

Three earthquake incidences which occurred in 1976 in the Lahad Datu area and 1991 and 2015 in Ranau area caused considerable damage to buildings (Tjia, 1978; Lim 1976 \& 1986; Lim \& Godwin, 1992; Tongkul, 1992 \& 2016). Another incidence caused minor damage to buildings in May 2008 in Kunak.

\section{MITIGATION OF EARTHQUAKES IN MALAYSIA}

Mitigation of earthquake involves receiving, analysing, maintaining, and distributing data on earthquake activity in Malaysia. This work is basically carried out by MMD through their network of seismograph stations. They provide rapid notification of earthquake events to civil defense and government officials in the affected area, and to the public through the news media. Mitigation also involves producing regional assessments of earthquake hazards in conjunction with State and local governments. The Minerals and 
Geoscience Department of Malaysia (JMG) produce the regional Seismic Hazard Map of Malaysia. This map is used by local planners and building officials in setting appropriate building and retrofitting standards in an area, government and civil defense officials in planning for disaster recovery, and professionals conducting detailed site assessments.

Basic research to learn more about the nature of earthquake activity is also part of the mitigation strategy. This research is mostly carried out by local universities in collaboration with foreign institutions. Apart from the scientific studies, education on earthquake hazards and safety to the public by publishing and distributing literature and various other outreach efforts is a must to mitigate earthquake. This public education is carried out by MMD, JMG and local universities in collaboration with the Malaysian National Disaster Management Agency (NADMA).

\section{A. Development of Seismic Hazard Map of Malaysia}

Seismic hazard is the hazard associated with potential earthquakes in a particular area, and a seismic hazard map shows the relative hazards in different areas. The maps are made by considering what we currently know about: (i) Past faults and earthquakes, (ii) The behaviour of seismic waves as they travel through different parts of the crust, and (iii) The near-surface site conditions at specific locations of interest. Hazard maps can be used for land-use planning, mitigation, and emergency response.

In late 2017 the first edition of seismic hazard map of Malaysia (JMG, 2018) was published by JMG and used in the Malaysia National Annex MS EN1998:2015 Eurocode 8; Design for Structures for Earthquake Resistance - Part 1: General Rules, Seismic Actions and Rules for Buildings. The seismic hazard map shows the probable peak ground acceleration (PGA) values for different parts of Malaysia. The seismic hazard map was developed by a group of local experts on earthquake comprising of various government agencies, non-government agencies and universities. The analysis is based on Probabilistic Seismic Hazard Assessment (PSHA) using active fault lines mapped by JMG and earthquakes from the Malaysia Meteorology Department (MMD) database and the United States Geological Survey (USGS) earthquake database.

An earlier seismic hazard map of Peninsular Malaysia was produced by Azlan et al. (2008) based on regional earthquakes from Indonesia. Similarly, (JMG, 2008) also produced a seismotectonic map of Malaysia. However, both studies were quite regional in nature and could not be used in formulating building codes. A global and regional seismic hazard map of Asia, which includes Malaysia was produced by Giardini et al. (1999) and Peterson et al. (2007). Both maps show PGA values that are not very different from the PGA values of the latest seismic hazard map of Malaysia. Another recent global seismic hazard map produced by the Global Earthquake Model (GEM) (Pagani et al., 2018) also shows nearly similar PGA values for Sabah.

The latest seismic hazard map by JMG shows that not all parts of Malaysia are exposed to significant peak ground acceleration of more than 4\%. In Peninsular Malaysia low PGA values make up around $60 \%$ of the total land area (Figure 7). The higher PGA values are concentrated in five areas, in Kuala Pilah, Bukit Tinggi, Manjung, Temenggor and Kenyir, coinciding with the presence of potential active faults in these areas. The highest PGA value of $9 \% \mathrm{~g}$ (0.09g) is located in Bukit Tinggi.

In Sarawak, low PGA values make up around 50\% ot the total area (Figure 8). The higher PGA values are concentrated in three areas, in Miri, Bukit Mersing (near Selangau) and Sri Aman, coinciding with the presence of potential active faults in these areas. The highest PGA value of $9 \% \mathrm{~g}$ (0.09g) is located in the Niah area.

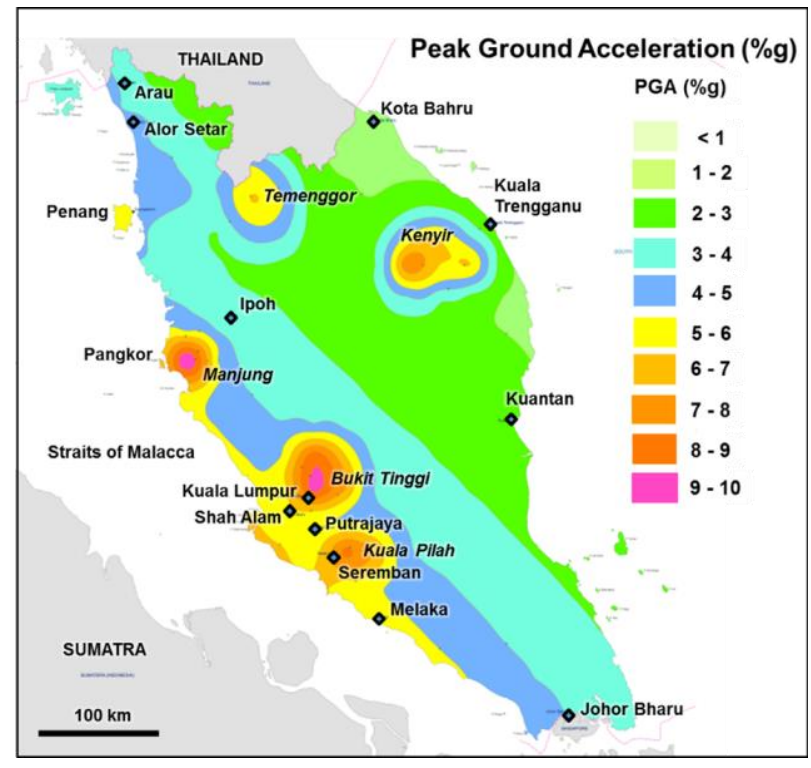

Figure 7. Seismic hazard map of 475 year return period Peak Ground Acceleration (PGA) on rock for Peninsular Malaysia. Source: JMG (2018) 


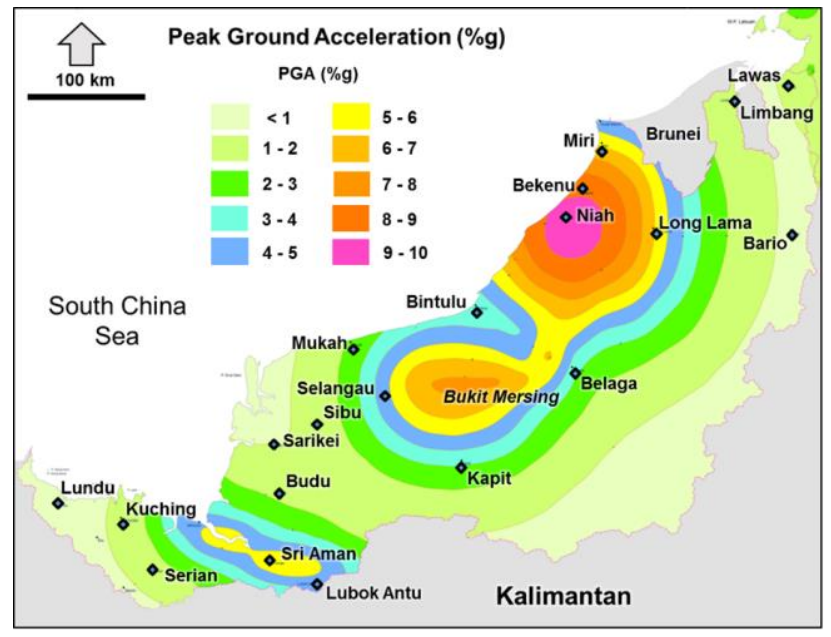

Figure 8. Seismic hazard map of 475 year return period Peak Ground Acceleration (PGA) on rock for Sarawak. Source: (JMG, 2018)

In Sabah, low PGA values make up around 30\% of the total area (Figure 9). The low PGA values are located in the southwest (e.g. Papar, Beaufort, Kuala Penyu, Sipitang, Tenom) whereas the higher values are located in the north (e.g. Kudat, Pitas, Kota Marudu), northeast (e.g. Paitan, Beluran, Sandakan, Sukau) and southeast (Lahad Datu, Kunak, Semporna, Tawau). The higher PGA values of more than $12 \%$ (o.12g) are concentrated in three areas, in Ranau, Kudat and Lahad Datu, coinciding with the presence of potential active faults in these areas. The highest PGA value of $16 \%(0.16 \mathrm{~g})$ is located in Lahad Datu. During the 2015 Ranau earthquake, the PGA value recorded by MMD for Ranau is $12.9 \%$ (0.129g), whereas for Tuaran is $4.4 \%$ (0.044g).

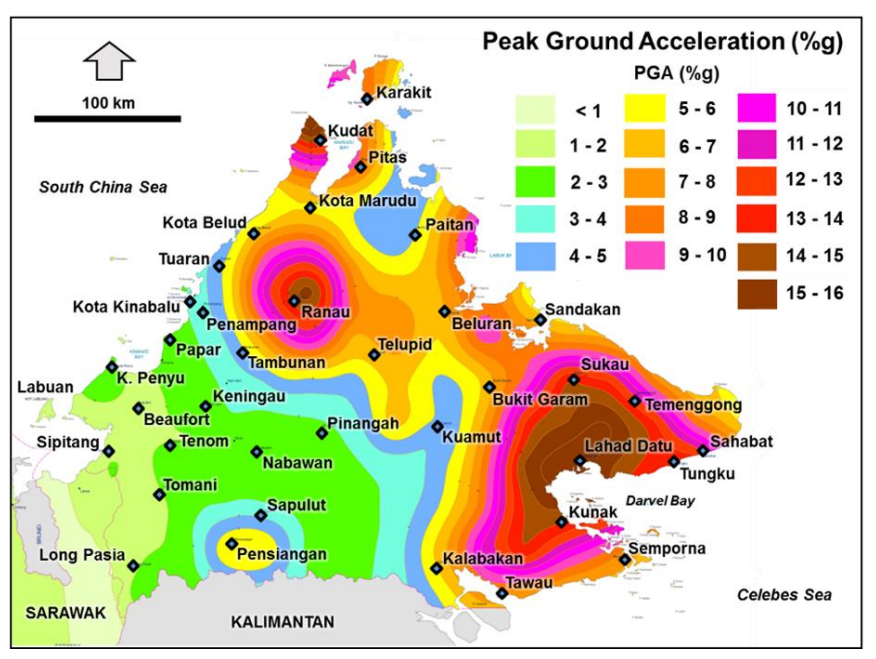

Figure 9. Seismic hazard map of 475 year return period Peak

Ground Acceleration (PGA) on rock for Sabah. Source:

(JMG, 2018)

\section{B. Development of National Seismic Building Code}

Building codes are designed to create quality assurance and durability, with the objective to minimise economic loss due to material and structural deterioration and to provide basic comfort and safety conditions. In earthquake-prone areas, building codes are complemented by seismic codes, specifying the calculation methods and strength values of key structural elements to avoid building collapse during an earthquake. In countries where building and seismic codes have not been implemented (e.g. Haiti, Pakistan, China, Nepal), large loss of life and economic set-back has occurred, compared to countries where seismic codes are strictly enforced (e.g. Peru, Chile, New Zealand and Japan) and the loss of life has been minimal.

In 2015 Malaysia adopted the MS EN1998: Eurocode 8; Design for Structures for Earthquake Resistance - Part 1: General Rules, Seismic Actions and Rules for Buildings. However, the annexe to the Eurocode 8 was only completed and published by the Department of Standards Malaysia (JSM) in late 2017 (JSM, 2017). The annexe was prepared by a group comprising officials from relevant government agencies such as MMD, JMG, Public Works Department (JKR), Sabah Housing and Real Estate Developers Association, Institution of Engineers Malaysia (IEM), Association of Consulting Engineers Malaysia and other seismic experts. With the Malaysian Annex publication to MS EN1998:2015 Eurocode 8, new buildings are expected to follow this code to withstand earthquakes better. However, it is not mandatory for all buildings to follow as it is up to the local authorities to impose such standards. Among the features that can be incorporated into buildings to help it weather earthquakes are the use of reinforced concrete and seismic rubber bearings. For existing buildings, it will be up to the owners' discretion to seek advice from professional engineers to assess whether such structures need to be upgraded or retrofitted to comply with the code.

\section{Development of Planning Guideline in High-risk Earthquake Area}

Following the physical impact of the 2015 Ranau Earthquake (6.o Mw) the Department of Town and Country Planning under the Ministry of Housing and Local Government (KPKT) was tasked with the preparation of a development guideline 
in high-risk earthquake area as a reference for state government, local government, implementing agencies, developers and consultants. The guideline which was completed in June 2018 provides a list of high-risk earthquake areas in Malaysia and proposed several mitigation measures in terms of planning and managing new developments in these areas (KPKT, 2018). The guideline emphasised the importance of using the National Seismic Hazard Map prepared by JMG in the preparation of development plan and approval of the development plan.

\section{Public Education Program}

MMD currently carries out public education on earthquake through their website. Information on the occurrence and records of an earthquake around Southeast Asia is readily available on their website. A recently developed shakemap called myGempa provides detailed information on the intensity of an earthquake. The department also routinely issue statements on the occurrence of earthquake within 8 minutes to the National Disaster Management Agency (NADMA) and the public via TV crawler, website, media statement and facebook. The department also organises seminars and workshops to share and disseminate earthquake-related studies and findings to the public.

Apart from MMD public education on earthquake is an ongoing activity by Universiti Malaysia Sabah (UMS) under the Natural Disaster Research Centre (NDRC). This seminar is carried out periodically in Sabah with collaboration from MMD, JMG and NADMA (Figure 10).

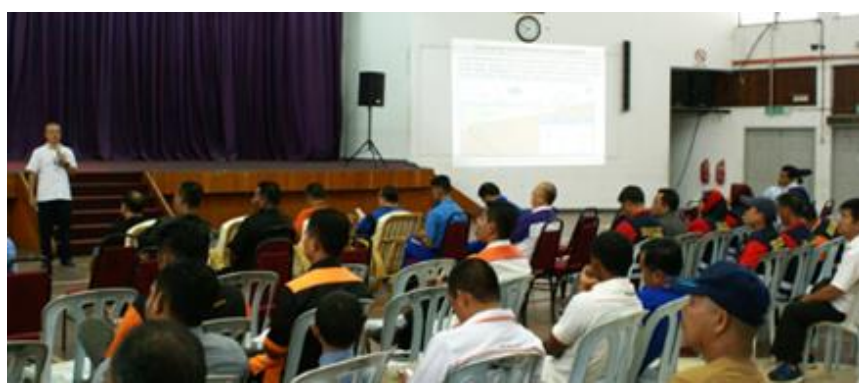

Figure 10. Public education seminar on earthquake science and earthquake preparedness in Kudat organised by UMS in 2017

From 2017-2019, UMS and UNICEF Malaysia with support from the Ministry of Education embarked on a two-year earthquake education program among school children and teachers in Ranau and Lahad Datu districts (Figure 11). All the 82 schools in Ranau and 53 schools in Lahad Datu benefited from this program.
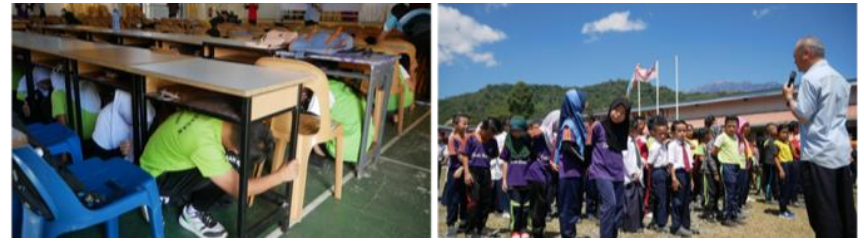

Figure 11: School children in Ranau learning about earthquake science and earthquake drill organised by UMS in 2018

\section{CHALLENGES IN EARTHQUAKE SCIENCE IN MALAYSIA}

Earthquake hazards are still poorly understood and yet to be properly quantified in Malaysia. This is due to the lack of basic scientific data. For example, during the 2015 Ranau earthquake, there was no usable earthquake hazard model or map which could be referred to for mitigation planning and reduction of impacts. Basic scientific data such as Peak Ground Acceleration (PGA) of the Ranau earthquake and past earthquakes was inadequate and not readily available for formulating a building code. The lack of engineering data on the strength of existing buildings adds to the problem of coming up with realistic guidelines for earthquake resistant building. The communities affected by the 2015 Ranau earthquake did not know what to do for several days as they were totally unprepared for the earthquake. Timely and appropriate information on the earthquake aftershocks lacked from MMD, and unfounded statements from the public regarding an impending large earthquake that went viral did not help calm the affected communities.

\section{A. Lack of Seismic, Geological, Geodetic and Engineering Data}

In order to properly quantify earthquake hazard, three basic pieces of information are needed: a model of future earthquakes, attenuation relations, and geologic site conditions. To come up with a model of future earthquake, information such as the past history of earthquakes, active faults (cause of earthquakes) and present crustal deformation (geodetic data) is required. In Malaysia, historical 
earthquakes are not well documented and archived. For example, in Sabah, only earthquake records after 2004 are complete. The older earthquake records are very patchy.

Conventional mapping of active faults has been ongoing for the past few years in Malaysia, primarily carried out by the JMG and UMS. Unfortunately, the precise location, rate of movement and detailed characteristics of active faults are still lacking. No attempt has yet been carried out to apply satellite remote sensing technology such as Interferometry Synthetic Aperture Radar (InSAR) to determine ground movement and thereby locate active faults. The use of adequately dense Global Navigation Satellite System (GNSS) network data to determine the crustal movement and seismic strain accumulation in a particular area has not been fully explored.

To determine on how the earthquake ground motion propagates from an earthquake source, a strong motion recordings close to the earthquake are required. In Malaysia strong motion seismic stations are already available in several locations. However, in order to estimate the surface ground motion of earthquake waves, it is necessary to know the seismic crustal velocity and geologic site condition. In Malaysia, such seismic crustal velocity model and geological information are also still lacking. An ongoing study by Cambridge University and the University of Aberdeen in collaboration with UMS and MMD to model the crustal velocity is currently limited to Sabah (Pilia et al., 2019).

Due to the incompleteness of available seismic, geological and geodetic data, the seismic hazard map of Malaysia produced by JMG can be considered a preliminary map that requires further revisions in the near future.

Basic information on the strength of existing buildings is needed to mitigate the impact of the future earthquake on buildings. At the same time, appropriate designs of the earthquake-resistant building are required. To achieve this, an earthquake engineering laboratory is needed to carry-out appropriate simulations and testing. Currently, such a facility is only available at Universiti Teknologi Malaysia (UTM). Even then, the facilities at UTM are inadequate and are quite old.

\section{B. Insufficient Seismic and Geodetic Monitoring System}

Data generated from continuous monitoring of earthquake activities and crustal movements can provide important clues as to where the next potential earthquakes will be located, apart from updating the existing seismic hazard map of Malaysia.

MMD solely carries out monitoring of earthquake in Malaysia. During the 2015 Ranau Earthquake, some of the seismic stations in Sabah experienced technical problems. As a result, critical data were missing, as there is no complementary seismic monitoring system in place. Although there are now 28 seismic stations installed and monitored by the MMD in Sabah, these are still not dense enough to provide accurate information, for research purpose (e.g. generating Focal Mechanism Solution - FMS). Blind spots exist in many places, especially in the Lahad Datu and Kunak areas.

Except for the MMD seismic data centre in Petaling Jaya, other seismological data centres are practically non-existent in Malaysia. A mirror site for earthquake monitoring was established by MMD in Kota Kinabalu since 2017 but is not well maintained due to lack of capable human resource.

In terms of crustal movement and deformation information on Malaysia 78 real-time GNSS network stations has been installed by the Department of Survey and Mapping Malaysia (JUPEM) for the past few years. In Sabah, there are 13 stations. However, the small number of stations, which is located tens of kilometres from each other do not provide high resolution crustal movement, associated with active faults and strained crustal areas. A pilot study to monitor crustal movement in Kundasang, Sabah by JUPEM yielded some results but was discontinued after a few years due to lack of funding (Azhari, 2012).

\section{Lack of Trained Human Resource}

Currently, the number of expertise in the field of earthquakerelated science and engineering is very small in local universities. They are distributed in different universities (e.g. UMS, UTM, UiTM, UPM, USM), carrying out their own research based on their individual expertise. JMG has only recently started to train their geologists to carry out mapping and monitoring of active faults.

The human resource in relevant departments, like MMD and JUPEM, is mostly focused on gathering data with limited data analysis capacity (advance research). Trained technicians in handling earthquake monitoring 
instrumentations are also limited. Local graduate students pursuing earthquake science and earthquake engineering degrees are very few.

\section{WAY FORWARD IN EARTHQUAKE SCIENCE IN MALAYSIA}

To ensure that the science of earthquake in Malaysia is up-todate and is able to respond to the current and future needs some steps have to be taken by all stakeholders involved in looking after the well-being of the people. The following are strategic measures to address the existing gaps, some which could be carried out immediately and others on a medium or long-term basis.

\section{A. Comprehensive Geological and Engineering Studies}

- Embark on using InSAR and GNSS to monitor minute (cm scale) surface ground deformation and crustal strain accumulation in earthquake-prone areas in Sabah. This could be quite useful in identifying active fault zones and locations of future earthquakes.

- Embark on crustal velocity studies using mathematical modelling for the whole country. This crustal velocity model could be useful in estimating the surface ground motion of an earthquake.

- Embark on soil studies in high risk areas to determine soil amplification values for generating appropriate response spectrum acceleration (RSA) for a specific location.

- Map potential earthquake-induced landslides and ground settlement due to liquefaction in high risk areas.

- $\quad$ Prepare hazard maps for earthquake-prone areas like Ranau and Lahad Datu (showing where landslides may occur and evacuation information). The map can be used to improve facilities for preventive and emergency measures.

- Develop a guideline for planning the development of land on or close to active faults.

- Identify cost-effective and easy methods to build earthquake-resistant houses in rural areas.

- Undertake seismic vulnerability studies of existing important buildings or structures, particularly in high risk areas.

\section{B. Coordinated Seismic and Geodetic Monitoring}

- Strengthen and improve seismic observation network under MMD by adding more sensitive seismic stations in strategic areas.

- Improve accuracy, timeliness and content of earthquake information products.

- Set up building acceleration instrumentation devices to obtain the acceleration at different storey height.

- Incorporate global seismic data, seismic hazard models and earthquake predictions to enhance local seismic models.

- $\quad$ Strengthen and improve GNSS observation network under JUPEM by adding more GNSS stations in strategic areas.

- $\quad$ Set up a complementary seismological and GNSS data centre, not only to process data but to carry out serious earthquake-related research (ideally located in Sabah).

\section{Human Resource Capacity Building}

- Develop human resource in the field of earthquake science and safety. Train more seismologists, earthquake scientists, earthquake engineers and earthquake technicians in relevant departments and universities to handle and interpret seismic instrumentations, and increase their capacities on these three aspects; i) mitigation and adaptation, ii) forecasting and iii) impact assessment on earthquake.

- Introduce earthquake science and earthquake engineering education curriculum in the local institution of higher learning.

- Allocate in-site supervision and enforcement in the government administration building at all levels, mainly related to the seismic code requirements.

\section{Coordinated Public Education}

- Increase public awareness of earthquake hazards 
and risks through a coordinated effort among institutions to ensure they are better prepared (more resilient) to respond to future earthquakes (during night-time or day-time).

- Implement seismic safety programs in schools.

- Awareness-raising on earthquake-resistant building techniques and preventive measurements, as many multi-storey buildings need structural retrofitting.

\section{E. Special Research and Development Fund}

- Provide support for basic research in geosciences, engineering, and social sciences phenomena on earthquake impacts, and means to reduce earthquake effects. This is essential to form the knowledge base from which targeted applied research and mitigation practices, and policies can be developed.

- Provide support for advanced scientific and engineering knowledge of earthquake effect on the built environment. This research will contribute in developing cost-effective design methodologies and technologies for mitigating these effects on soils, existing structures and new construction. This will also contribute to the formulation of building codes.

- $\quad$ Provide support to determine the available strength of various building types prevalent in the country, to identify their deficiencies and weaknesses from a seismic behaviour point of view, and work out how such deficiencies and weaknesses can be eliminated or minimised by feasible and economic actions in the field. The objective of such intervention would be to reduce the risk of total collapse and prevent the loss of life as well as the loss of contents in future earthquake occurrences.
- $\quad$ Provide support to develop building code versions which are understandable and affordable to local village craftsmen in rural areas who normally build their houses without plans or calculations using selfhelp methods.

- Support the development of guidelines and instructions for community-based assessment of seismic hazards.

\section{F. National Earthquake Research Centre}

- Set-up teaching, research and mitigation of earthquake hazards that provided earthquake science and engineering laboratories equipment at National Earthquake Research Centre.

- Earthquake science and earthquake engineering expertise could be pooled together at this centre to serve a common goal

\section{ACKNOWLEDGEMENT}

I would like to thank UMS for providing logistical support and financial assistance through Project DGBooo1 and Project STDooo8 to carry out this research. I would also like to thank the MMD and JMG for providing seismic data and geological data, respectively. I would like to thank all my research collaborators on earthquake science from Universiti Malaysia Sabah, Universiti Malaya, Universiti Kebangsaan Malaysia, Universiti Teknologi Malaysia, Universiti Sains Malaysia, Nanyang Technological University, University of Cambridge and the University of Aberdeen for their valuable contribution to my research knowledge and experience. I would also like to thank the two anonymous reviewers for their constructive comments.

\section{REFERENCES}

Azhari, BM 2012, 'Monitoring active faults in Ranau, Sabah using GPS': Proceeding of the 19th United Nations Regional Cartographic Conference for Asia and the Pacific. 29 October 2012, Bangkok, Thailand.

Azlan, A, Hendriyawan, Aminton, M \& Masyhur I 2006, 'Development of seismic hazard maps for peninsular
Malaysia', Journal of Science and Technology in the Tropics, vol. 3, no. 1, pp. 51-57.

Giardini, D, Grunthal, G, Shedlock, KM \& P. Zhang 1999,

'The GSHAP global seismic hazard map', Annali Di Geofisica, vol. 42, no. 6, pp. 1225-1230.

Hall, R 2013, 'Contraction and extension in northern Borneo 
driven by subduction rollback', Journal of Asian Earth Sciences, vol. 76, pp. 399-411.

Hesse, S, Back, S \& Franke, D 2009, 'The deep-water foldand-thrust belt offshore NW Borneo: gravity-driven versus basement-driven shortening', Geological Society of America Bulletin, vol. 121, no. 5-6, pp. 939-953.

Ismail, AR, Tongkul, F, Mustaffa, KS, Tajul, AJ, Alexander, YSW, Mohd Rosaidi, CA, Noraini, S, Rozaini, I, Mohd Nazan, A, Ferdaus, A, Mohamad, M, Bailon, G, Henry, LA, Ledyhernando, T, Zaidi, D, Roziah, CM, Zahid, A, Rabieahtul, AB, Khamarrul, AR \& Harry, B 2015, Remote sensing and field survey analysis of active faults in tectonically active areas in Malaysia, Sciencefund Project 04-01-10-SFo201 Technical Report for MOSTI, pp. 124.

JMG 2018, 'Seismic hazard map of Malaysia', 1st Edition, Ministry of Natural Resources and Environment.

JMG 2008, 'Asssessment of seismic threats to Malaysia from major earthquakes in the Southeast Asian region', Seismic and tsunami hazards and risks in Malaysia, Ministry of Natural Resources and Environment, pp. 97.

JSM 2017, 'Design of structures for earthquake resistance', in Part 1: General rules, seismic actions and rules for buildings, Ministry of International Trade and Industry, MS EN 1998-1:2015 (National Annex 2017) Malaysian National Annex to Eurocode 8, pp. 39.

King, RC, Backe', G, Morley, CK, Hillis, RR \& Tingay, MRP 2010, 'Balancing deformation in NW Borneo: quantifying plate-scale vs. gravitational tectonics in a delta and deepwater fold-thrust belt system', Marine and Petroleum Geology, vol. 27, pp. 238-246.

JPB dan Desa 2018, Garis Panduan Perancangan: Pembangunan Dan Pengurusan Di Kawasan Berisiko Bencana Gempa Bumi, Kementerian Perumahan dan Kerajaan Tempatan, pp. 62.

Leyu, CH, Chang, CF, Arnold, EP, Kho, SL, Lim, YT, Subramaniam, M, Ong, TC, Tan, CK, Yap, KS, Shu, YK \& Goh, HL 1985, 'Series on Seismology, Volume III Malaysia', Southeast Asia Association of Seismology and Earthquake Engineering, pp. 99.

Lim, PS \& Godwin, P 1992, 'The Ranau earthquake swarm, May-July 1991, Sabah', in: Proceedings of the 23rd Geol. Conf. Geol. Survey Malaysia, vol. 4, pp. 168-193.

Lim, PS 1976, Earth tremors in Eastern Sabah, Malaysia Geological Survey Annual Report 1976, pp. 220-223.

Lim, PS 1985, 'History of earthquake activities in Sabah, 1897-1983', Geological Survey Malaysia Annual Report 1983, pp. 350-357.
Lim, PS 1986, 'Seismic activities in Sabah and their relationship to regional tectonics', Geological Survey of Malaysia Annual Report 1985, pp. 465-480.

Mustafar, MA, Simons, WJF, Tongkul, F, Satirapod, C, Omar, KM \& Visser, P 2017, 'Quantifying deformation in North Borneo with GPS', J Geodesy, vol. 91, pp. 1241-1259.

Mustafar, MA, Simons, WJF, Omar, KM \& Ambrosius, BAC 2014, 'Monitoring of local deformations in North Borneo', in Proceedings of FIG Congress 2014, Engaging the Challenges, Enhancing the Relevance, 16 - 21 June 2014, Kuala Lumpur, Malaysia.

Shuib, MK, Manap, MA, Tongkul, F, Abd Rahim, IB, Jamaludin, TA, Surip, N, Bakar, RA, Abas, MRC, Musa, RC \& Ahmad, Z 2017, 'Active faults in Peninsular Malaysia with emphasis on active geomorphic features of Bukit Tinggi region', Malaysian Journal of Geoscience, vol. 1, no. 1, pp. 13-26.

Natawidjaja, DH \& Triyoso, W 2007, 'The Sumatra fault zone: from source to hazard', in: From Source to Hazard, Proceedings of 2007 Workshop on Earthquake and Tsunamis National University of Singapore, 7-9 March 2007.

Pagani, M, Garcia-Pelaez, R, Gee, R, Johnson, V, Poggi, V, Styron, R, Weatherill, G, Simionato, M, Viganò, D, Danciu, L \& Monelli, D 2018, Global Earthquake Model (GEM) Seismic Hazard Map.

Petersen, M, Harmsen, S, Mueller, C, Haller, K, Dewey, J, Luco, N, Crone, A, Lidke, D \& Rukstales, K 2007, 'Documentation for the Southeast Asia Seismic Hazard Maps', Administrative Report 30 September 2007, U.S. Department of the Interior.

Pilia, Simone, Rawlinson, Nicholas, Gilligan, Amy \& Tongkul, F, 2019, 'Deciphering the fate of plunging tectonic plates in Borneo', Eos. 100.

Rangin, C, Bellon, H, Benard, F, Letouzey, J, Muller, C \& Sanudin, T 1990, 'Neogene arc-continent collision in Sabah, Northern Borneo (Malaysia)', Tectonophysics, vol. 183, no. 1-4, pp. 305-319.

Sapin, F, Hermawan, I, Pubellier, M, Vigny, C \& Ringenbach, JC 2013, "The recent convergence on the NW Borneo Wedge-a crustal-scale gravity gliding evidenced from GPS', Geophysical Journal International, vol. 193, no. 2, pp. $549-556$.

Tjia, HD 1978, 'The Lahad Datu (Sabah) earthquake of 1976: surface deformation in the epicentral region', Sains Malaysiana, vol. 7, no. 1, pp. 33-64.

Tjia, HD 2007, 'Kundasang (Sabah) at the intersection of 
regional fault zones of Quaternary age', Bull. Geol. Soc. of Malaysia, vol. 53, pp. 59-66.

Tongkul, F 2017, 'Active tectonics in Sabah - seismicity and active faults', Bull. Geol. Soc. Malaysia, vol. 64, pp. 27-36.

Tongkul, F 2016, 'The 2015 Ranau earthquake: cause and impact', Sabah Society Journal, vol. 32, pp. 1-28.

Tongkul, F 1992, 'The Ranau earthquake: possible causes', Sabah Society Journal, vol. 9, no. 4, pp. 315-322.

Tongkul, F 1991, 'Tectonic evolution of Sabah, Malaysia', Journ. Southeast Asian Earth Science, vol. 6, no. 3/4, pp. 395-405.

Tongkul, F 1989, 'Recent strike-slip fault movement associated with a mud volcano in the Lahad Datu area, Sabah', Sains Malaysiana, vol. 18, no. 1, pp. 23-31.

Tongkul, F \& Omang, SAK 2010, 'Geological studies of active faults in Ranau and Lahad Datu Areas, Sabah', Final report of FRGS Project FRGoo93-ST-1/2006 submitted to MOHE, pp. 44.

Wang, Y, Wei, S, Wang, X, Lindsey, E, Tongkul, F, Bradley, KE, Chung-Han, C, Hill, E \& Kerry Sieh, K 2017, 'The 2015 Mw 6.o Mt. Kinabalu earthquake: an infrequent fault rupture within the Crocker fault system of East Malaysia'. Geosci. Lett. vol. 4, no. 6, pp. 1-12.

Walpersdorf, A, Vigny, C, Subarya, C \& Manurung, P 1998, 'Monitoring of the Palu-Koro Fault (Sulawesi) by GPS', Geophysical Research Letters, vol. 25, no. 13, pp. 23132316.

Wilford, GE 1967, 'Earth tremors in Sabah', Sabah Society Journal, vol. 3, pp. 136-138. 